DOI https://doi.org/10.32837/app.v0i67.1144

УДК 323.15

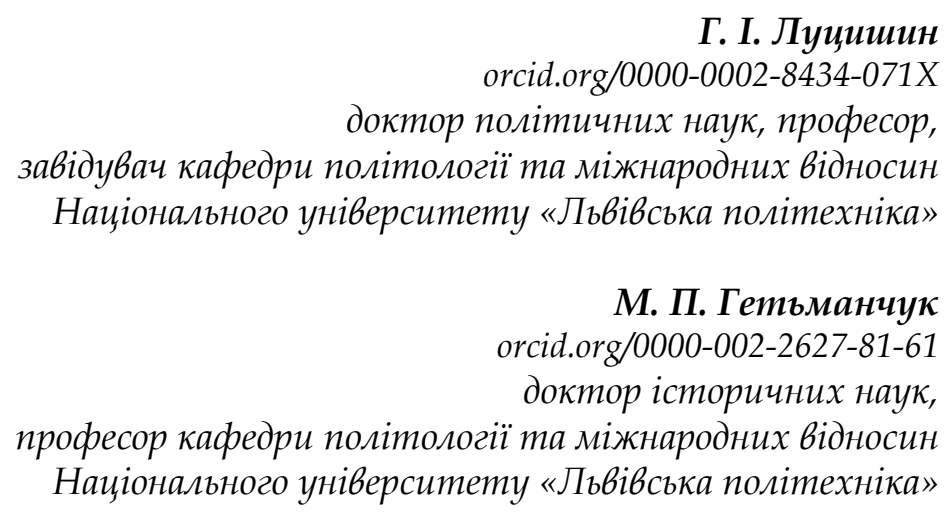

\title{
ДОСЛІДЖЕННЯ ПИТАННЯ НАЦІОНАЛЬНОЇ КОНСОЛІДАЦІЇ ТЕОРЕТИКАМИ УКРАЇНСЬКОГО НАЦІОНАЛІЗМУ
}

Одним із найбільш суперечливих явищ суспільного життя, яке впливає не тільки на європейську, а й на світову історію, є національне питання. Зарубіжні дослідники небезпідставно констатують, що на цьому етапі розвитку людства не просто примножилася кількість держав, а саме поняття національної держави ще міцніше закріпилося у світі: 1) національна держава продовжує залишатися єдиною міжнародною визнаною структурою політичного об'єднання, і лише вона допускається до вступу в ООН та міжнародні організації; 2) після 1991 р. більше 18 нових національних держав були визнані «державами-спадкоємцями», а це сталося після сорокарічного періоду суцільних відмов з боку наддержав надавати подібний статус; 3) чималим і різноманітним є спектр сучасних національних держав, на одному кінці якого перебувають національні держави, в яких домінує етнічне ядро, а на іншому - етнічно глибоко розділені національні держави із значними етнічними й національними меншинами; 4) національна держава до цього часу залишається єдиною ареною для розв'язання етнічних проблем як однієї із важливих умов розбудови держави (Сміт, 2006, с. 146-148).

Необхідно зазначити, що сьогодні в Україні відсутня загальноприйнята методологічна модель, яка узагальнювала б та інтегрувала теоретичні напрацювання вітчизняних науковців стосовно проблеми національної консолідації як основи стратегії національного державотворення. Вітчизняні дослідники відзначають, що ідеологічна невизначеність, відсутність ціннісних орієнтацій та усвідомленої мети і завдань суспільного розвитку, домінування партикулярних інтересів над загальнонаціональними, внутрішні та зовнішні гібридні виклики для національної безпеки вимагають чіткого визначення теоретико-методологічних засад ідеології державного будівництва, основою для якого стала б об' єднувальна національна ідея консолідації українського суспільства. Саме вказані причини сьогодні уможливлюють наступ на національну ідентичність українців і стали одним із проявів російської гібридної агресії (Світова гібридна війна, 2017, с. 251-256). Найбільш радикальною формою несприйняття Російською Федерацією української ідентичності стало заперечення онтологічного статусу українства взагалі.

В основі розвитку кожної суверенної і демократичної держави лежить внутрішня соціально-політична інтеграція суспільства, а ії стрижнем є національна консолідація. Кожна держава, в тому числі й Україна, намагається вибудовувати свою модель національної консолідації, оскільки вона є важливим засобом досягнення соціальної, політичної та міжнаціональної згоди в суспільстві, одним із механізмів зміцнення державного суверенітету та формування сучасної політичної нації. Однак, як зазначав відомий чеський державний діяч і науковець Т. Масарик, єдиного шаблону для вирішення всіх національних питань немає. Він підкреслює, що правильне поєднання природного та історичного права у цьому процесі можливе лише при обов' язковому врахуванні мови народів та їх національної приналежності (Масарик, 2007, с. 80-81). 
Досліджуючи проблему національної консолідації, можна переконатися, що вже на ранніх етапах розвитку політичної думки науковці та політичні діячі розглядали різні шляхи забезпечення єдності тогочасних держав. Значний внесок у вивчення проблеми національної консолідації зробили українські вчені теоретики націоналізму. В українській науковій політичній думці XIX - XX століть інтерес до проблем національної консолідації, формування та розвитку націй має доволі поважну історію як у сфері ідеологічних розробок (Д. Донцов, В. Липинський, М. Сціборський та ін.), так і в загальних наукових дослідженнях (О. Бочковський, В. Старосольський, I. Лисяк-Рудницький та ін.). Особливу увагу до проблем розвитку нації, національної консолідації приділяли представники громадівського напряму - В. Антонович, М. Драгоманов, С. Подолинський. М. Драгоманов як один із провідних українських науковців цього періоду намагався теоретично доказати, що єдність українського народу на його етнічних територіях має активно сприяти духовному і політичному зближенню українського населення Наддніпрянщини, Галичини, Буковини й Закарпаття (Луцишин, 2012, с. 20-24).

У наукових та публіцистичних працях М. Драгоманов наголошував на цілісності та єдності українських земель, вважаючи їх поділ між чужоземними державами історично зумовленим, а отже, скороминучим. Провідну роль у процесі національної консолідації він відводив інтелігенції. Для М. Драгоманова пропаганда національної виключності, формування в українській свідомості ідеї ненависті до інших людей за етнічною ознакою, навіть до тих, що належали до пануючих над українцями народів, була неприйнятним способом відродження України. Українська справа, на думку вченого, полягала у не просто у звільненні України та відновленні ії державно-політичної самостійності, а у свободі представників тих соціальних верств, що репрезентували українську націю, зберегли вірність мові і національним традиціям (Круглашов, 2000, с. 188). Підтвердженням того, що праці М. Драгоманова мали глибокий науковий зміст та концептуальний характер, є і те, що їх використовували у своїй роботі такі відомі європейські дослідники та науковці, як М. Вебер та Т. Масарик.

Наголошуючи на причинах, що негативно позначалися на об'єднавчих національних процесах, М. Драгоманов звертав увагу на включення української еліти у духовний та політичний процес функціонування владних еліт Російської та Австро-Угорської імперій, асинхронність ритмів розвитку українського суспільства не лише у австрійській та російській Україні, а навіть між Галичиною й Буковиною, з одного боку, та Закарпаттям - з іншого. Регіональні відмінності об'єктивно спричиняли локалізацію українського суспільно-політичного та інтелектуального життя. Наголошуючи на етнографічній єдності українців Росії й АвстроУгорщини, він акцентував увагу на необхідності створення єдиного українського духовного простору за допомогою вироблення єдиної української мови, обміну книжками, збирання етнографічних матеріалів, заснування загальноукраїнських наукових інституцій. Українська «колонізація окраїн», як вказував М. Драгоманов, має значно зміцнити державність та забезпечити стабільність (Драгоманов, 1991, с. 430-460).

Своє бачення проблем національної консолідації висловлювали також відомі теоретики українського націоналізму - М. Міхновський, О. Бочковський, М. Сціборський, М. Донцов, С. Бандера та ін. Для української нації та національної єдності, наголошували М. Сціборський та О. Бочковський, важливими є психологічні чинники - національна свідомість і воля. Як член Проводу та ідеолог ОУН М. Сціборський розробив основні принципи націократії, які виклав в однойменному творі, що вийшов друком у 1935 р. Основними засадами націократії він називає: національну солідарність; авторитарність; суспільну ієрархію та дисципліну; самоорганізацію і самоврядність. Головну роль у націоконсолідуючих процесах, стверджує він, відіграє держава, яка трактується як найбільш оптимальна форма існування нації: «Тільки через власну державу нація стає творчим чинником історії й повноправним господарем своєї власної долі. Без цього нація завжди й неминуче стає предметом поневолення й визиску інших державних націй» (Сціборський, 2007, с. 102).

Розглядаючи питання національної єдності, М. Сціборський наголошує, що нація - це не механічний збір певної кількості людей, пов'язаних спільністю території, мови й матеріальних інтересів, а найвища органічна форма людського співжиття, яка має неповторний внутрішній і духовний зміст, утворений з прадавніх часів на підставі природних властивостей цієї людської спільності, її моральної єдності та прагнення здійснювати свої власні історич- 
ні завдання. Ідеологія націоналізму М. Сціборського побудована на максималізмі, любові до своєї нації і нетерпимості до всього чужого, готовності боротьби проти всіх сил, котрі заважають розвитку нації. Він, зокрема, стверджує, що без держави нація не може зберегти своєї єдності, вона буде приречена на поділ між іншими державами, що обов'язково приведе до руїни і саму націю (Сціборський, 2007, с. 102-105).

Вітчизняні дослідники зазначають, що початковий етап українського націоналізму пов' язаний з постаттю М. Міхновського, а другий етап, після Першої світової війни, - 3 постаттю Д. Донцова. Саме вони стали творцями двох напрямів в українському націоналістичному русі: 1) М. Міхновський - демократичного націоналізму; 2) Д. Донцов - інтегрального націоналізму (Мала енциклопедія етнодержавознавства, 1996, с. 719-722; Касьянов, 1999). У своїй національно-політичній програмі «Самостійна Україна» основоположник модерного українського націоналістичного руху М. Міхновський відзначав, що нація може розвиватися вільно з користю для їі членів лише тоді, коли матиме власну самостійну державу. Державна самостійність $є$ головною умовою існування нації, а державна незалежність - національним ідеалом у сфері міжнаціональних відносин (Міхновський, 2006, с. 426). Ставши на такі ідейні позиції, він визначив і другу засаду українського націоналізму, а саме здійснення національного визволення та об'єднання української нації прийде лише в результаті переможної боротьби з поневолювачами. Завданням українського націоналізму є організація народу для такої боротьби, яка має завершитися створенням «єдиної, нероздільної, вільної самостійної України від Карпат аж по Кавказ» (Міхновський, 2006, с. 432).

Ідеологія інтегрального націоналізму Д. Донцова, який він називав «чинним націоналізмом», спиралася на засади філософського волюнтаризму, антидемократизму, політичного і соціального ієрархізму. Розробляючи концепцію «правлячої касти» - єдиного виразника національної волі, він стверджував, що лише «ініціативна меншість» є рушійною силою історії. Відкидаючи принцип народоправства, Д. Донцов заявляв, що «ініціативна меншість», а не народ, є предметом історичних процесів (Донцов, 2006, с. 69-75). Він вказував, що для національної консолідації важливим є розуміння нації як спільноти, об'єднаної насамперед духовними чинниками, серед яких чільне місце посідав спільний ідеал як спільне бачення майбутнього й бажання творити це майбутнє спільними зусиллями.

Україна, як зазначає Д. Донцов, завжди першою приймала натиск московської політичної, соціальної та культурної експансії на Захід. У цьому і полягає головна суть нашої національної ідеї, зовнішньополітичної стратегії та нашої геополітичної значимості в регіоні Середньої та Східної Свропи - у боротьбі проти хаосу на Сході, це захищати свою власну державність та культуру, одночасно обороняючи загалом усі цивілізаційно-культурницькі цінності Заходу. Д. Донцов наголошував, що насправді від долі України в цій боротьбі залежала перемога одного з обох принципів на континенті: європейського або московського (Сосновський, 2006, с. 664-666). У своїх геополітичних візіях ставить наголос на зміцненні та консолідації Середньої Європи, яка через свою слабкість та розбалансованість знаходиться під постійною загрозою з боку Москви та залишається відкритою для ії агресивної політики. В цьому контексті Дмитро Донцов виносить на перше місце українсько-польське порозуміння, усвідомлюючи ключову роль України у регіоні Середньої і Східної Свропи. 3 цього приводу він наголошує, що ключі до опанування слов'янства (а через нього і Свропи) - може дістати лише той, хто володіє Україною (Донцов, 2001, с. 83-85).

Головним стратегічним партнером серед європейських країн у боротьбі з Росією Донцов однозначно вбачає Польщу. Хоча він і зауважує, що у нас із поляками ще багато не вирішених проблем, але вони носять локальний характер і на загальний стан українсько-польських відносин вирішального впливу не будуть мати. Адже російський імперіалізм для досягнення своїх геополітичних цілей передбачає знищення Києва і Варшави як незалежних політичних центрів. Але, щоб цього не сталося, неообхідно опертися на ті європейські держави, які нині виступають проти російського імперіалізму. 3 цього приводу Донцов слушно посилається на висловлювання Герцена: «Росія може оволодіти Свропою до Атлантичного океану, так само, як вона може бути переможеною аж до Уралу. В першому випадку - Свропа мусить бути порізненою. В другому - Свропа повинна бути міцно об'єднана в одне ціле» (Донцов, 1957, с. 99; Квіт, 2013, с. 44-45). 
Вагомий внесок у дослідження проблеми національної консолідації зробили у своїх працях відомий український державний діяч В. Старосольський, один із провідних європейських фахівців 3 теорії націй і національних відносин О. Бочковський, а також відомий український політичний та громадський діяч Ю. Бачинський. Досліджуючи проблему національної консолідації в Україні, В. Старосольський відзначав, що вона може бути реалізована через культурні особливості нації, які з часом переростають у політичні, і лише тоді нація стає державою (Старосольський, 1998, с. 57). Водночас О. Бочковський наголошував, що ключову роль у націєтворчому процесі відіграє національна свідомість, яка є основою нації та держави. Зокрема, в процесі націотворення він виділяє два етапи: період етногенези (для європейських націй VIII - XVI ст.) і націогенези (починаючи з XVI ст. етнічне усвідомлення виростає до висунення політичної ідеї і розпочинається період націогенези). Вчений підкреслював, що процес націотворення може відбуватися як «знизу» - на органічній основі, так і «згори» - на політичній основі, за допомогою держави (Бочковський, 1998, с. 138). У своїх працях Ю. Бачинський обгрунтовує роль економічного фактору у процесі становлення української нації та шляхів ії консолідації (Бачинський, 2006, с. 414-424). Особливої уваги в наш час заслуговує висловлена Ю. Бачинським думка про те, що боротьба за самостійність України не стосується лише виключно українського народу, а є справою всіх національностей, що заселяють ії територію (Бачинський, 1924, с. 173-181).

Особливу увагу проблемі національної консолідації України приділяв у своїх працях відомий український політичний діяч, ідеолог українського державотворення В. Липинський, який визначив формулу української державності через консенсус та консолідацію. Він, зокрема, наголошував, що національною цінністю, навколо якої потрібно консолідуватися українцям, повинна стати проста і прагматична ідея - побудова цивілізованого заможного суспільства на основі нових демократичних форм соціальної кооперації. Шлях до такого суспільства лежить через відновлення фундаментальних цінностей та відродження спільного історичного підгрунтя українського народу. Тому В. Липинський закликав: «Через загальне добро України - до добра ії громадян, через добро ії громадян - до добра тих народів, членами яких є ці громадяни» (Липинський, 1995, с. 153). Актуальною є думка вченого про те, що тільки за умови існування об'єднуючої ідеї української національної незалежності можна говорити про існування української нації. Соціальна й національна консолідація, зазначав В Липинський, мають будуватися на основі територіального та громадянського патріотизму. Він слушно зауважував, «що ніхто ніколи нам не збудує державу, коли ми самі ії не збудуємо, і ніхто з нас не зробить нації, коли ми самі нацією не хочемо бути» (Липинський, 1995, с. 153).

Консолідувати націю, вивести іiї з кризи (національної, соціальної, політичної) можна лише спираючись на повноцінне національне виховання, яке передбачає цілеспрямоване формування у особистості позитивного ставлення до базових національних цінностей, що $\epsilon$ несумісними з національним нігілізмом і шовінізмом. Національне виховання, підкреслював В. Липинський, сприяє забезпеченню духовної єдності, наступності та спадкоємності поколінь минулих, сучасних і майбутніх, формує національну свідомість. Найбільш прийнятним шляхом формування української нації він вважав «територіальний патріотизм», тобто солідарність усіх постійних жителів, для яких українська земля стала спільною батьківщиною. При цьому В. Липинський зазначав, що консолідуючим чинником для української нації є ії перемоги - «нації творяться перемогами» (Липинський, 1995, с. 175).

Проблема національної консолідації є однією з ключових у працях С. Бандери після 1945 року. Об'єднати всі сили, сконсолідувати їх в одну цілість, без затрати їхньої окремішньої специфіки - це було, за словами С. Бандери, найважливіше завдання. Він підкреслює, що «сама механічна консолідація, про яку звичайно думає велика більшість їі речників, - напевно не принесла б поважних позитивних наслідків. Навпаки, коли б ми пов'язали різні політичні угруповання тільки формально, а вони далі хотіли б іти власними політичними шляхами, не тільки у другорядних питаннях, а й у принципових справах української внутрішньої і зовнішньої політики, - то у висліді, замість скріплення, було б послаблення, замість об'єднання взаємне паралізування» (Бандера, 1946). 
Він критикує «механічний» підхід до національної консолідації, і перш ніж давати відповідь на питання, яка консолідація в нас є можлива і потрібна, доцільно з'ясувати позитивне розуміння цієї проблеми. На думку С. Бандери, першою і головною передумовою участі в політичній консолідації $є$ те, щоб політичні угруповання керувалися одним основним політичним імперативом змагання за здійснення головної мети: самостійної Української держави, і з тією метою підпорядкували всі свої вужчі, партійні інтереси. Друга передумова до повної політичної консолідації - це визнання тільки одного шляху, щоб досягти ту спільну мету. Як підкреслював С. Бандера, «основне правило, випробуване й утверджене історичним досвідом народів, наказує, що навіть тоді, коли перед політикою нації, як цілості, відкривається більше шляхів, вона не повинна розділятися, а в найважливіших справах мусить зберегти свою одностайність. Політична та національна консолідація не може бути самоціллю, а є засобом, політичним інструментом (Бандера, 1946).

Довший час як в Україні, так і в багатьох європейських країнах втілювалася політика жорсткого централізму, держава залишалась основним консолідуючим чинником, а нація ставала синонімом держави. Зацікавлення національною проблематикою було практично мінімальним. Тільки із середини XIX ст. століття серед українських та європейських науковців проблематика національних питань стає однією з актуальних та дискусійних. Епоха національного відродження в країнах Європи актуалізувала питання розвитку націй, національної ідеї та національної ідентичності як основи для процесів консолідації. Відомий британський дослідник Е. Сміт, визначаючи зміст поняття «нація», звертає увагу на те, що це складна конструкція з багатьох взаємопов' язуючих компонентів - етнічних, культурних, територіальних, економічних, політико-правових (Сміт, 1994, с. 24). Національна ідея, як відзначають вітчизняні науковці, - це також складна структура. Вона складається із багатьох взаємозумовлених елементів: 1) національної ідентичності; 2) національного покликання; 3) національного ідеалу; 4) національних інтересів; 5) національних цінностей та пріоритетів (національної держави, національної стратегії, національної безпеки) (Фартушний, 2000). Сформована національна ідентичність - це ототожнення людини з певною соціальною спільнотою, внутрішнє сприйняття людиною цінностей, ідеалів, зразків поведінки відповідної етнічної спільноти. Національна консолідація також є одним із складних та багатовимірних понять, змістом якого $є$ нація, національна ідея, національна ідентичність, національні інтереси, національні символи, національні лідери тощо.

Підсумовуючи, варто відзначити, що національна консолідація розглядається у світовій та українській політичній думці у XX - XXI століть як важливий процес націєтворення. Відомий американський дослідник С. Гантінгтон зазначає, що, визначаючи сьогодні власну ідентичність в етнічних чи релігійних термінах, люди схильні розглядати відносини між собою та представниками інших етносів і конфесій як відносини «ми» і «вони». Кінець ідеологізованих держав у Східній Європі та на території колишнього СРСР дав можливість вийти на передній план традиційним формам етнічної ідентичності, а відмінності в культурі або релігії породжують розбіжності у важливих політичних питаннях та утруднюють процес політичної консолідації (Huntington, 1990). Аналіз наукової літератури засвідчує, по-перше, актуальність дослідження проблеми національної консолідації в Україні для розвитку національного будівництва та державницької практики; по-друге, відсутність комплексного, системного дослідження із вказаної проблематики.

\section{Лimepamypa}

Бандера С. До проблеми політичної консолідації // Визвольна політика. Лондон. 1946. Ч. 4-5, червень-липень [Електронний ресурс]. - Режим доступу: http: // maidan.org.ua/static/mai/1304854379.html. Бачинський Ю. Україна irredenta. 3-тє вид. Берлін: Видавництво української молоді, 1924. 237 с.

Бачинський Ю. Економічні підстави самостійності націй // Націоналізм: Антологія. 2-ге вид. Київ: Смолискип, 2006. С. 414-424.

Бочковський О. Вступ до націології. Київ: Генеза, 1998. 338 с.

Донцов Д. Твори. Т. 1. Геополітичні та ідеологічні праці. Львів: Кальварія, 2001. 488 с.

Донцов Д. Ідеологія чинного націоналізму / / Націоналізм: Антологія. 2-ге вид. Київ: Смолискип, 2006. С. 69-75. 
Донцов Д. Підстави нашої політики. Нью-Йорк, 1957. 210 с.

Драгоманов М.П. Вибране («...мій задум зложити очерк історії цивілізації України»). Київ: Либідь, 1991. 688 с.

Касьянов Г.В. Теорії нації та націоналізму. Київ: Либідь, 1999. 352 с.

Квіт С. Дмитро Донцов: ідеологічний портрет. Вид. друге. виправ. і доп. Львів: Галицька видавнича спілка, 2013. 192 с.

Круглашов А.М. Драма інтелектуала: Політичні ідеї Михайла Драгоманова. Чернівці: Прут, 2000. 488 с. Липинський В. Повне зібрання творів, архівів, студій. Т. 6. Кн. 1. Листи до братів-хліборобів. Про ідею і організацію українського монархізму. Київ-Філадельфія: Інститут Східноєвропейських досліджень НАН України, 1995. 470 с.

Луцишин Г.І. Національна консолідація України в умовах сучасного політичного процесу: монографія. Львів: Видавництво Львівської політехніки, 2012. 364 с.

Масарик Т.Г. Право і демократія. Вибрані праці. Київ: Логос, 2007. 336 с.

Мала енциклопедія етнодержавознавства. Київ: Довіра, 1996. 942 с.

Міхновський М. Самостійна Україна // Націоналізм: Антологія. 2-ге вид. Київ: Смолискип, 2006. С. $425-433$.

Світова гібридна війна: український фронт. Харків: Фоліо, 2017. 496 с.

Сміт Е.Д. Нація і націоналізм у глобальну епоху; пер. з англ. Київ: Видавництво Ніка-Центр, 2006. 320 с. Сміт Е.Д. Національна ідентичність; пер. $з$ англ. Київ: Основи, 1994. 223 с.

Сосновський М. Ідеологія «чинного націоналізму» Д. Донцова // Націоналізм: Антологія. 2-ге вид. Київ: Смолискип, 2006. с. 628-674.

Старосольський В.Й. Теорія нації. Київ: Вища школа, 1998. 143 с.

Сціборський М. Націократія. Вінниця, 2007. 112 с.

Фартушний А. Українська національна ідея як підстава державотворення. Львів: Видавництво НУ «Львівська політехніка», 2000. 307 с.

Huntington S.P. Who are We? The Challengers to America's National Identity. New Delhi: Penguin Books, 2004. $428 \mathrm{p}$.

\section{References}

Bandera S. (1946) Do problem politychnoi konsolidacii [To the problem of political consolidation]. London. 1946. Ch. 4-5. Cherven-lypen [Electronnyj resurs]. Rezym dostupu: http://maidan.org.ua/static/ mail/1304854379.html,

Bachunskyj Yu. (2006) Ekonomichni pidstavy samostijnosti naciy [Economic grounds for the independence of nations] // Nacionalizm: Antolohija. 2-he vyd. Kyiv: Smolyskyp, 2006. [in Ukrainian]

Bachynskyj Yu. (1924) Ukraina irredenta [Ukraine is an irredent]. Berlin: Wydavnyctvo ukrainskoyi molodi, 1924. [in Ukrainian]

Bochkovskyj O. (1998) Wstup do naciolohiyi [Introduction to nationalism]. Kyiv: Heneza, 1998. [in Ukrainian] Doncov D. (2001) Tvory. T. 1. Heopolitychni ta ideolohichni praci [Writings. T. 1. Geopolitical and ideological works]. Lviv: Kalvariya, 2001. [in Ukrainian]

Doncov D. (2006) Ideolohiya chynnoho nacionalizmu [Ideology of current nationalism]. Kyiv: Smolyskyp, 2006. [in Ukrainian]

Doncov D. (1957) Pidstavy nashoyi polityky [The basis of our policy]. New York, 1957. [in Ukrainian]

Drahomanov M.P. (1991) Wybrane («...miy zadum zlozyty ocherk istoriy cyvilizacii na Ukrainie» [Selected]. Kyiv: Lybid, 1991. [in Ukrainian]

Kasjanov H.W. (1999) Teorii nacii ta nacionalizmu [Theories of nation and nationalism]. Kyiv: Lybid, 1999. [in Ukrainian]

Kvit S. (2001) Dmytro Doncov: ideolohichnyj portret. Wyd. druhe, wypr. i dop. [Dmitry Doncov: an ideological portrait]. Lviv: Halycka wydavnycha spilka, 2001. [in Ukrainian]

Kruhlashov A.M. (2000) Drama intelektuala: politychni idei Mychajla Drahomanova [Drama of an intellectual: political ideas of Mikhail Drahomanov]. Czernivci: Prut, 2000. [in Ukrainian]

Lypynskyj W. (1995) Povne zibrannia tvoriv, archiviv, studiy. [Complete collection of works, archives, studies]. T. 6. Kn. 1. Lysty do brativ-chliborobiv. Pro ideyu i orhanizaciyu ukrainskoi monarchii. Kyiv-Filadelfiya: Instytut Schidnoslovianskych doslidzen NAN Ukrainy, 1995. [in Ukrainian]

Lucyshyn H.I. (2012) Nacionalna konsolidacija Ukrainy $\mathrm{v}$ umovach suchasnoho politychnoho procesu [National consolidation of Ukraine in the conditions of modern political process]. Lviv: Wydavnyctvo Lvivskoji politechniky, 2012. [in Ukrainian] 
Masaryk T.H. (2007) Pravo i demokratija: Wybrani tvory [Law and democracy: Selected works]. Kyiv: Lohos, 2007. [in Ukrainian]

Mala encyklopedija etnoderzavoznavstva (1996) [A small encyclopedia of ethno-state studies]. Kyiv: Dovira, 1996. [in Ukrainian]

Michnovskyj M. (2006) Samostijna Ukraina [Independent Ukraine] // Nacionalizm: Antolohija. 2-he wyd. Kyiv: Smolyskyp, 2006. [in Ukrainian]

Svitova hibrydna wijna: ukrajinskyj front (2017) [World hybrid war: Ukrainian Front]. Za zah. red. W.P. Horbulina. Charkiv: Folio, 2017. [in Ukrainian]

Smit E.D. (2006) Nacija i nacionalizm u hlobalnu epochu [Nation and nationalism in the global era]. Kyiv: Wydavnyctvo Nika-Centr, 2006. [in Ukrainian]

Smit E.D. (1994) Nacionalna identychnist [National identity]. Kyiv: Osnovy, 1994. [in Ukrainian]

Sosnovskyj M. (2006) Ideolohija chynnoho nacionalizmu D. Doncova [Ideology of current nationalism D. Doncov] // Nacionalizm: Antolohija. 2-he wyd. Kyiv: Smolyskyp, 2006. [in Ukrainian]

Starosolskyj W.Yu. (1998) Teorija nacii [Theory of the nation]. Kyiv: Wyshcza shkola, 1998. [in Ukrainian]

Sciborskyj M. (2007) Naciokratija [Nationocracy]. Winnycia, 2007. [in Ukrainian]

Fartushnyj A. (2000) Ukraynska nacionalna ideja jak pidstava derzavotvorennia [Ukrainian national idea as the basis of state formation]. Lviv: Wydavnyctvo NU «Lvivska politechnika», 2000. [in Ukrainian]

Huntington S.P. (2004) Who are We? The Challengers to America's National Identity. New Delhi: Penguin Books, 2004.

\section{Анотація}

Луциииин Г. І., Гетьманчук М. П. Дослідження питання національної консолідації теоретиками українського націоналізму. - Стаття.

У статті розглянуто питання національної консолідації українського суспільства у працях провідних теоретиків українського націоналізму. Досліджено бачення проблем національної консолідації відомими теоретиками українського націоналізму - М. Міхновським, О. Бочковським, М. Сціборським, М. Донцовим, С. Бандерою та ін. Наголошено, що питання національної консолідації вітчизняні дослідники українського націоналізму почали вивчати у XIX - XX століттях і розглядали їі як важливий процес соціально-політичного націєтворення. Доведено, що теоретики українського націоналізму досліджували такі аспекти політичної та культурної інституалізації національної консолідації: 1) зовнішній аспект, який передбачав вплив геополітичних чинників на процес національної консолідації; 2) внутрішній, що зумовлений історичними, культурними, релігійними, мовними, ментальними особливостями українського суспільства. Проаналізовано механізми досягнення національної консолідації суспільства в Україні, які залежать від особливостей боротьби українського народу за незалежність, національних традицій, національної свідомості, шляхів формування національної ідентичності, політичної культури, рівня соціально-економічного розвитку. Висвітлено концептуальні підходи представників українського націоналізму до використання форм, методів і засобів формування національної консолідації українського суспільства на різних етапах історичного розвитку. 3'ясовано, що врахування зовнішніх та внутрішніх чинників національної консолідації забезпечить в Україні стабільний розвиток національного державотворення. Особливий наголос у процесі національної консолідації представниками націоналізму робиться на питаннях національної свідомості, національного виховання, яке передбачає цілеспрямоване формування в особистості позитивного ставлення до базових національних цінностей, забезпечення духовної єдності, наступності та спадкоємності поколінь минулих, сучасних і майбутніх.

Kлючовi слова: українська політична думка націоналістичного спрямування, нація, національна консолідація, національна ідентичність, націоналізм, міжнаціональні відносини.

\section{Summary}

Lutsyshyn H. I., Hetmanchuk M. P. Research on the issue of national consolidation by theorists of Ukrainian nationalism. - Article.

The article considers the issue of national consolidation of Ukrainian society in the works of leading theorists of Ukrainian nationalism. The vision of the problems of national consolidation is studied by well - known theorists of Ukrainian nationalism - M. Mikhnovsky, O. Bochkovsky, M. Stsiborsky, M. Dontsov, S. Bandera and others. It is emphasized that domestic researchers of Ukrainian nationalism began to study the issue of national consolidation in the XIX-XX centuries and considered it as an important process of sociopolitical nation-building.

The mechanisms of achieving national consolidation of society in Ukraine are analyzed, which depend on the peculiarities of the Ukrainian people's struggle for independence, national traditions, national 
consciousness, ways of forming national identity, political culture, level of socio-economic development. The conceptual approaches of the representatives of Ukrainian nationalism in the use of forms, methods and means of forming the national consolidation of Ukrainian society at different stages of historical development are highlighted.

The conceptual approaches of the representatives of Ukrainian nationalism in the use of forms, methods and means of forming the national consolidation of Ukrainian society at different stages of historical development are highlighted. It was found that only taking into account the external and internal factors of national consolidation will ensure the stable development of national statehood in Ukraine.

In the process of national consolidation, the representatives of nationalism make special emphasis on issues of national consciousness, national upbringing, which provides for the purposeful formation of a positive attitude to basic national values, ensuring spiritual unity, continuity and succession of past, present and future generations.

Key words: Ukrainian political thought of nationalist orientation, nation, national consolidation, national identity, nationalism, interethnic relations. 